\title{
PENGEMBANGAN SISTEM INFORMASI MANAJEMEN PRAKTEK KERJA LAPANGAN BERBASIS WEB UNTUK MENINGKATKAN LAYANAN ADMINISTRATIF PROGRAM STUDI TEKNIK INFORMATIKA UNIVERSITAS MATARAM DI ERA PANDEMI COVID-19
}

\author{
(Development Of Web-Based Professional Placement Management Information \\ System to Improve Administrative Services In Informatics Engineering University of \\ Mataram In The Era of The Covid-19 Pandemic)
}

\author{
Andy Hidayat Jatmika ${ }^{[1]}$, Ariyan Zubaidi ${ }^{[1]}$, Ahmad Zafrullah Mardiansyah $^{[1]}$, Ari Hernawan ${ }^{[1]}$, I Gde Putu \\ Wirarama Wedashwara Wirawan ${ }^{[1]}$ \\ ${ }^{[1]}$ Dept Informatics Engineering, Mataram University \\ J1. Majapahit 62, Mataram, Lombok NTB, INDONESIA \\ Email:[andy, zubaidi13, zaf, arihernawan,wirarama]@unram.ac.id
}

\begin{abstract}
Abstrak
Salah satu layanan administratif di Program Studi Teknik Informatika Universitas Mataram adalah layanan administratif Praktek Kerja Lapangan (PKL). PKL merupakan salah satu mata kuliah wajib dengan bobot 2 (dua) SKS yang harus ditempuh oleh mahasiswa Program Studi Teknik Informatika. dimana pelaksanaannya langsung di lapangan, industri ataupun instansi, sehingga mahasiswa diwajibkan untuk menyelesaikan proses administrasi seperti pendaftaran PKL hingga surat menyurat ke instansi yang dituju. Di masa pandemi Covid-19 ini, layanan harus dilakukan secara daring. Namun layanan administratif secara daring tersebut masih belum optimal karena dilakukan melalui media seperti Website, Email dan WhatsApp yang tentu saja dilihat dari sudut pandang manajemen pengelolaan tidak terlalu baik. Permasalahan yang ada saat ini adalah pencatatan dan penyimpanan data mahasiswa PKL kurang terstruktur dan kurang rapi, memerlukan waktu yang lama dalam hal pencarian data mahasiswa yang akan melakukan kegiatan PKL dan mahasiswa yang sudah melakukan kegiatan PKL pada tahun sebelumnya, adanya redudansi data sehingga data tidak konsisten. Disamping itu, dikarenakan adanya aturan dari pemerintah untuk melaksanakan kegiatan secara daring, prosedur layanan menggunakan media Email dan WhatsApp masih merepotkan dan tidak optimal. Tujuan dari pelaksanaan kegiatan pengabdian kepada masyarakat ini adalah untuk mengembangkan sebuah sistem informasi manajemen praktek kerja lapangan berbasis web yang dapat diakses kapan saja dimana saja sehingga memberikan solusi terbaik terhadap permasalahan-permasalahan yang ada di Prodi Teknik Informatika Unram. Selain itu, sistem informasi manajemen praktek kerja lapangan tersebut dapat melakukan serangkaian aktifitas pengolahan data yang dapat menghasilkan informasi yang dibutuhkan oleh pengelola prodi maupun mahasiswa.
\end{abstract}

Keywords: sistem informasi, website, praktek kerja lapangan, teknologi, pendidikan.

\section{Pendahuluan}

Di era pandemi Covid-19 saat ini, pendidikan di Indonesia merupakan salah satu yang terkena dampak paling besar. Pembatasan yang dilakukan selama dua minggu diharapkan bisa mengurangi resiko tingkat persebaran virus Covid-19, tetapi ternyata hal ini tidak berjalan seperti yang direncanakan. Hal ini mengakibatkan seluruh sekolah di Indonesia, mulai dari jenjang Taman Kanak-kanak sampai Universitas meliburkan peserta didiknya, karena dikhawatirkan bahwa tingkat kerumunan yang tinggi bisa menjadi cluster baru pada persebaran Covid-19 [1].

Pandemi Covid-19 merupakan tantangan bagaimana menyikapinya dalam melaksanakan kegiatan pembelajaran, karena pola pembelajaran pada era pandemi ini menggunakan sistem daring dimana manusia dituntut untuk dapat mengkondisikan atas terjadinya fenomena ini sehingga pembelajaran dapat berjalan lancar dan sukses. Di tengah masa pandemi Covid - 19 muncul sebuah aturan terutama di Indonesia yang dimana masyarakat Indonesia diharuskan untuk menjaga jarak antara satu dengan yang lain minimal satu setengah meter 
sehingga masyarakat Indonesia dipaksa untuk stay at home / dirumah saja dan melakukan seluruh aktivitas dari rumah termasuk bekerja dan belajar.

Program Studi Teknik Informatika merupakan institusi pendidikan di bawah naungan Fakultas Teknik Universitas Mataram yang sejak tahun 2020 telah melaksanakan proses pembelajaran secara daring selama pandemi covid-19. Tidak hanya pembelajaran, layanan administratif pun dilakukan secara daring. Salah satu layanan administratif tersebut adalah layanan administratif Praktek Kerja Lapangan (PKL). Namun layanan administratif yang dilakukan secara daring tersebut masih belum optimal karena dilakukan melalui media seperti Website, Email dan WhatsApp yang tentu saja dilihat dari sudut pandang manajemen tidak terlalu baik. PKL merupakan salah satu mata kuliah wajib dengan bobot 2 (dua) SKS yang harus ditempuh oleh mahasiswa Program Studi Teknik Informatika. dimana pelaksanaannya langsung di lapangan, industri ataupun instansi, sehingga mahasiswa diwajibkan untuk menyelesikan proses administrasi seperti pendaftaran PKL hingga surat menyurat ke instansi yang dituju.

Prosedur administratif PKL yang saat ini dilakukan secara daring selama pandemi covid-19 adalah mahasiswa mengunduh form yang terdapat di website resmi Prodi Teknik Informatika kemudian mengisi form tersebut lalu mengirim ke prodi melalui email dan melakukan konfirmasi ke staf prodi melalui WhatsApp. Permasalahan muncul ketika form yang dikirim mahasiswa melalui email resmi prodi ikut tercampur dengan email lainnya sehingga meyulitkan staf prodi untuk mendata dan mengelola form yang telah dikirim tersebut, dari sisi mahasiswa yang mengurus PKL juga akan menunggu sangat lama. Selain itu staf administrasi prodi juga melakukan permintaan nomor surat ke protokol Fakultas dengan mengirim pesan melalui WhatsApp dimana cara ini juga sangat tidak efektif dan membutuhkan waktu yang lama. Permasalahan lainnya adalah pencatatan dan penyimpanan data kurang terstruktur dan kurang rapi, memerlukan waktu yang lama dalam hal pencarian data mahasiswa yang akan melakukan kegiatan PKL dan mahasiswa yang sudah melakukan kegiatan PKL pada tahun sebelumnya, adanya redudansi data sehingga data tidak konsisten, Disamping permasalahan tersebut, prodi juga belum memiliki sistem yang dapat mengelola data PKL mahasiswa dari proses pendaftaran, pengajuan surat menyurat, penunjukkan dosen pembimbing oleh kaprodi, pengajuan seminar PKL, berita acara PKL, dan sebagainya.

Dengan adanya permasalahan-permasalahan yang telah disebutkan, maka tujuan pelaksanaan kegiatan pengabdian kepada masyarakat ini adalah untuk mengembangkan sebuah sistem informasi manajemen praktek kerja lapangan berbasis web yang dapat diakses kapan saja dimana saja sehingga memberikan solusi terbaik terhadap permasalahan-permasalahan yang ada di Prodi Teknik Informatika Unram. Selain itu, sistem informasi manajemen praktek kerja lapangan tersebut dapat melakukan serangkaian aktifitas pengolahan data yang dapat menghasilkan informasi yang dibutuhkan oleh pengelola prodi maupun mahasiswa.

\section{TINJAUAN PUSTAKa}

Pada bagian ini akan dijelaskan tinjauan pustaka yang digunakan dalam kegiatan pengabdian kepada masyarakat di Program Studi Teknik Informatika. Tinjauan pustaka memuat tentang sistem informasi manajemen dan teknologi web service dalam pengembangan sistem PKL.

\subsection{Sistem Informasi Manajemen}

Manajemen dapat menjadi sumber informasi termasuk informasi penting dalam proses pengambilan keputusan. Untuk mengolah dan memanfaatkan data-data dengan maksimal. Cara kerja sistem informasi manajemen, dimulai dari pengolahan data kemudian disimpan dalam database terpusat dimana informasi dapat diakses dan di-update oleh semua orang yang memiliki wewenang sesuai dengan tujuan mereka.

Seperti yang dilakukan oleh kantor BPKAD NTB [2], penerapan sistem informasi manajemen juga dilakukan untuk mempermudah manajemen aset pada kantor mereka. Berdasarkan hasil kuesioner yang diperoleh, responden pada Kantor BPKAD setuju bahwa sistem informasi manajemen yang dibuat dapat membantu pegawai dan telah berjalan dengan baik.

Manfaat Sistem Informasi Manajemen adalah [3]:

a. Meningkatkan efisiensi dan efektivitas data secara akurat dan realtime.

b. Memudahkan untuk melakukan perencanaan, pengawasan, pengarahan dan pendelegasian kerja kepada semua departemen yang memiliki hubungan atau koordinasi.

c. Meningkatkan kualitas sumber daya manusia karena unit sistem kerja yang terkoordinasi dan sistematis.

d. Meningkatkan produktivitas dan penghematan biaya dalam organisasi. 


\subsection{Teknologi Web Service}

Pemanfaatan teknologi internet telah mewarnai perkembangan sistem distributed computing dengan munculnya konsep web services. Web services merupakan paradigma baru dalam mengimplementasikan sistem terdistribusi melalui web yang menggunakan basis teknologi XML, dengan standard protokol HTTP dan SOAP. Mengingat standard terbuka yang digunakan dalam mendukung teknologi web services, maka implementasi web services memberikan kemudahan dan perbaikan dalam mendukung integrasi berbagai platform sistem dan aplikasi, baik melalui infrastruktur intranet maupun internet atau ekstranet.

Adanya Web-Service memudahkan perpaduan fungsi dalam membangun sebuah program aplikasi tanpa bergantung lagi pada sistem operasi maupun bahasa pemrograman yang digunakan. Teknologi web service yang dibangun mampu mengintegrasikan sistem layanan administrasi PKL dan dapat didistribusikan ke banyak pengguna dengan kebutuhan yang berbeda-beda [4].

Konsep arsitektur yang mendasari teknologi Web service adalah Service Oriented Architecure (SOA)[5], SOA mendefinisikan 3 peran berbeda yang menunjukkan peran dari masing- masing komponen dalam sistem, yaitu [6]:

1. Service provider, yaitu suatu entitas yang menyediakan web service yang menjalankan sekumpulan tugas tertentu.

2. Service requestor, yaitu suatu entitas yang meminta suatu fungsionalitas tertentu dari web service.

3. Service registry, yaitu entitas yang menyimpan berbagai service yang disediakan oleh Service Provider .

\subsection{Basis Data}

Basis data terdiri dari 2 kata, yaitu basis dan data. Basis kurang lebih diartikan sebagai markas atau gudang, tempat bersarang/berkumpul. Sedangkan data adalah representasi fakta dunia nyata yang mewakili suatu objek seperti manusia, barang, hewan, peristiwa, konsep, keadaan, dan sebagainya, yang direkam dalam bentuk angka, huruf, simbol, teks, gambar, bunyi/suara, atau kombinasinya [7].

\subsection{Aplikasi Berbasis Web}

World Wide Web atau yang biasa disebut web, merupakan salah satu sumber daya internet yang berkembang pesat. Teknologi web memanfaatkan bahasa yang disebut HTML (Hyper Text Markup Language) dan protokol yang digunakan dinamakan HTTP (Hyper Text Tansfer Protocol) [8]. Pada perkembangan berikutnya, sejumlah skrip dan objek dikembangkan untuk memperluas kemampuan HTML, seperti PHP, ASP, dan applet (Java). Sedangkan website merupakan sebuah kumpulan halaman-halaman web beserta file-file pendukungnya, seperti file gambar, video, dan file digital lainnya yang disimpan pada sebuah web server yang umumnya dapat diakses melalui internet.

\section{Metode Pengabdian masyarakat}

Gambar 1 merupakan diagram alir yang menggambarkan metode pelaksanaan kegiatan atau langkah-langkah yang akan dilakukan dalam kegiatan pengabdian kepada masyarakat ini.

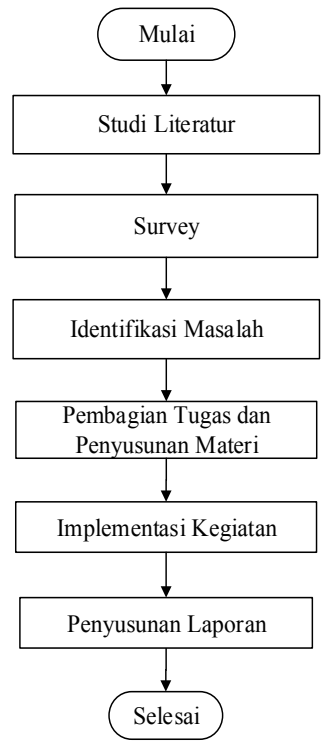

Gambar 1. Diagram alir metode kegiatan 
a. Studi Literatur

Pada tahap ini, dilakukan pengkajian terhadap berbagai sumber mengenai trend perkembangan teknologi dalam membangun Sistem Informasi Manajemen PKL berbasis Web.

b. Survei

Tim pengabdian melakukan survei ke Program Studi Teknik Informatika Fakultas Teknik Universitas Mataram yang akan dijadikan lokasi pelaksanaan kegiatan pengabdian masyarakat.

c. Identifikasi Masalah

Tim pengabdian melakukan observasi dan wawancara terhadap staf administrasi, dosen, dan mahasiswa terkait proses bisnis atau prosedur yang dilakukan untuk melakukan kegiatan PKL.

d. Pembagian Tugas

Untuk dapat melaksanakan kegiatan ini, tim terlebih dahulu berkoordinasi untuk menentukan waktu pelaksanaan kegiatan, pembagian tugas dan peran masing-masing anggota tim. Tim juga menghubungi atau berkoordinasi dengan pihak Prodi Teknik Informatika Universitas Mataram untuk memberikan informasi kesediaan sebagai tempat kegiatan.

e. Implementasi Kegiatan

Kegiatan pengembangan Sistem Informasi Manajemen PKL berbasis Web akan dilakukan di Laboratorium milik Program Studi Teknik Informatika Fakultas Teknik Universitas Mataram dengan menerapkan protokol kesehatan covid-19. Pada kegiatan pengabdian ini, tim melibatkan 2 (dua) orang mahasiswa yang turut membantu dalam pengembangan sistem informasi manajemen PKL agar mereka memperoleh pengalaman dan mengasah kemampuan yang dimiliki. Dalam mengembangkan Sistem Informasi Manajemen PKL ini dilakukan dengan beberapa tahapan yaitu:

1. Pembuatan desain tampilan atau layout web.

2. Melakukan pemrograman web

3. Pengumpulan data-data yang dibutuhkan

4. Melakukan web hosting

f. Penyusunan Laporan

Pada tahap ini dilakukan penyusunan laporan akhir dari kegiatan pengabdian kepada masyarakat yang telah dilakukan. Laporan akhir ini merupakan salah satu pertanggungjawaban tim terhadap kegiatan pengabdian yang telah dilakukan.

\section{HaSil dan PeMbahasan}

\subsection{Pembuatan Kode Program}

Pada tahap ini dilakukan pembuatan kode program sistem informasi manajemen PKL yang melibatkan seluruh anggota tim pengabdian sesuai dengan tugas masing-masing, disamping itu terdapat 2 (dua) orang mahasiswa dari Program Studi Teknik Informatika Universitas Mataram yang dilibatkan untuk membantu kegiatan pengabdian kepada masyarakat ini. Pembuatan kode program dilakukan tiap minggunya di Laboratorium Komunikasi Data dan Sistem Tertanam milik Program Studi Teknik Informatika Fakultas Teknik Universitas Mataram, selain itu juga agar memudahkan komunikasi dan koordinasi antar anggota dalam hal pembuatan modul-modul kode program.

Modul-modul yang dibangun adalah modul yang terkait fungsi-fungsi atau fitur seperti pengajuan PKL, Seminar PKL, dan fungsi Pengaturan untuk pengelolaan oleh admin sistem. Dalam hal pembuatan kode program yang melibatkan mahasiswa, ketua pengabdian selalu melakukan pendampingan dan monitoring tiap minggunya agar apa yang telah direncanakan dapat berjalan dengan baik dan sesuai dengan tujuan. Keterlibatan dan pendampingan mahasiswa dalam pembuatan kode program dapat dilihat pada Gambar 2 dan Gambar 3. 


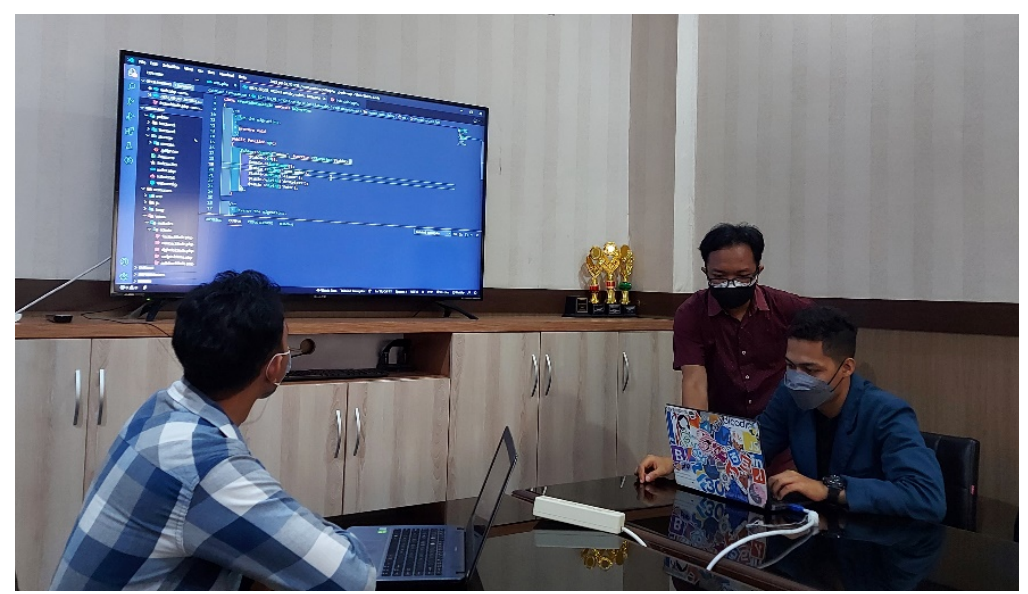

Gambar 2. Pembuatan kode program yang melibatkan mahasiswa

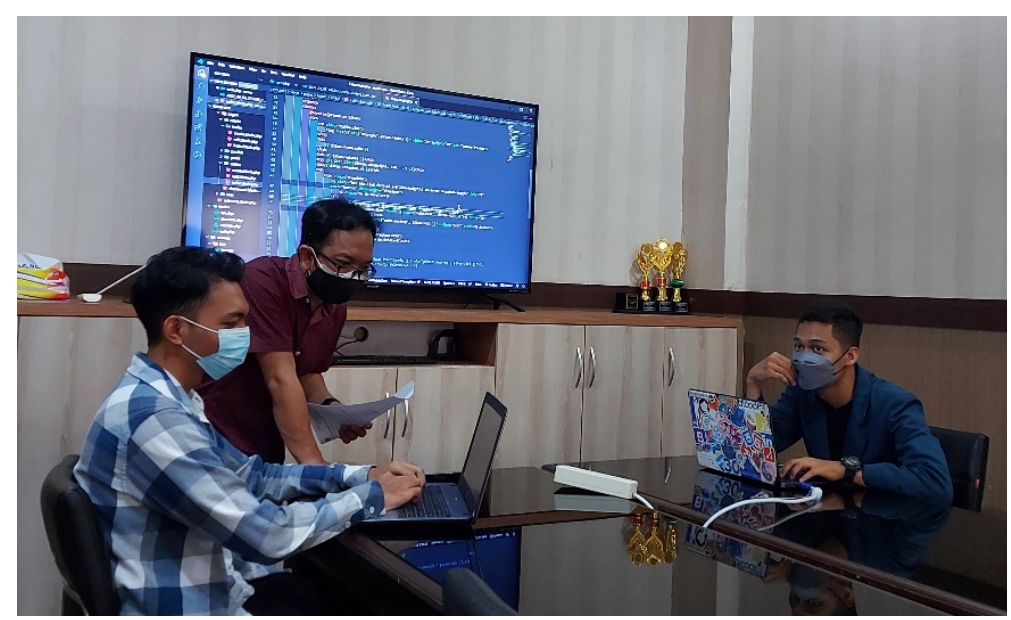

Gambar 3. Pendampingan oleh ketua pengabdian dalam menyusun kode program

\subsection{Implementasi Sistem}

Pada bagian ini akan disajikan tampilan antarmuka dari Sistem Informasi PKL yang telah dibangun, seperti halaman depan, halaman login, halaman beranda, halaman pengajuan PKL, halaman seminar PKL, dan halaman pengaturan untuk admin sistem.

a. Halaman Depan

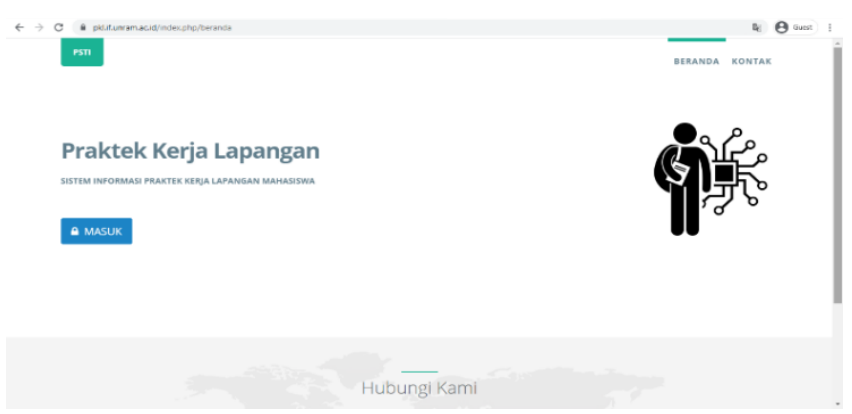

Gambar 4. Halaman Depan Sistem Informasi PKL 
Gambar 3 merupakan tampilan awal dari sistem informasi PKL. Di halaman ini, user harus login terlebih dahulu menggunakan username dan password yang telah terdaftar di database sistem single sign on milik Universitas Mataram.

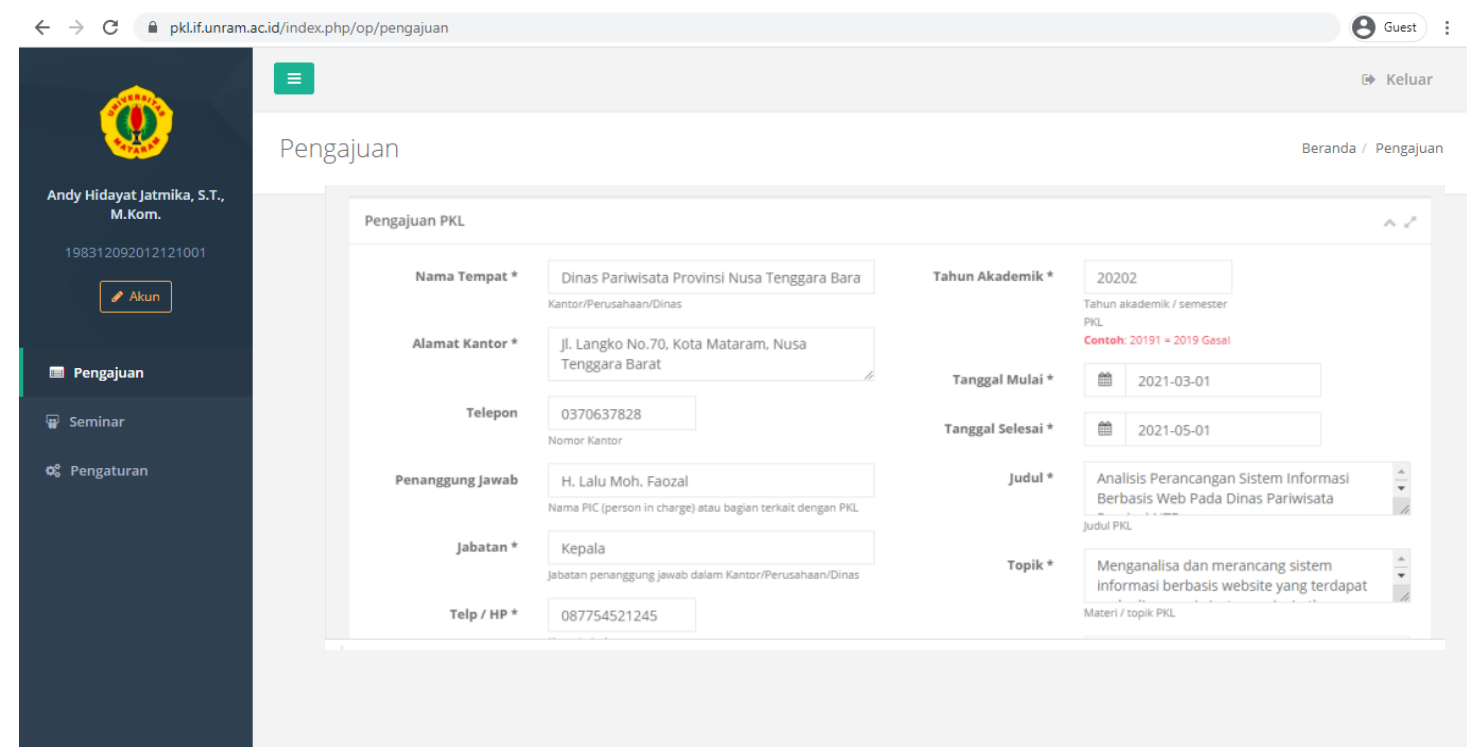

Gambar 5. Halaman pengajuan PKL

Pada halaman Dashboard terdapat 3 pilihan menu yaitu Pengajuan, Seminar, dan Pengaturan. Pada Gambar 5 ketika user memilih menu pengajuan, akan muncul beberapa isian yang harus dilengkapi yaitu lokasi tempat PKL, alamat, nomor telepon, penanggung jawab, jabatan, nomor HP, tahun akademik, tanggal mulai dan selesai PKL, judul dan topik PKL.

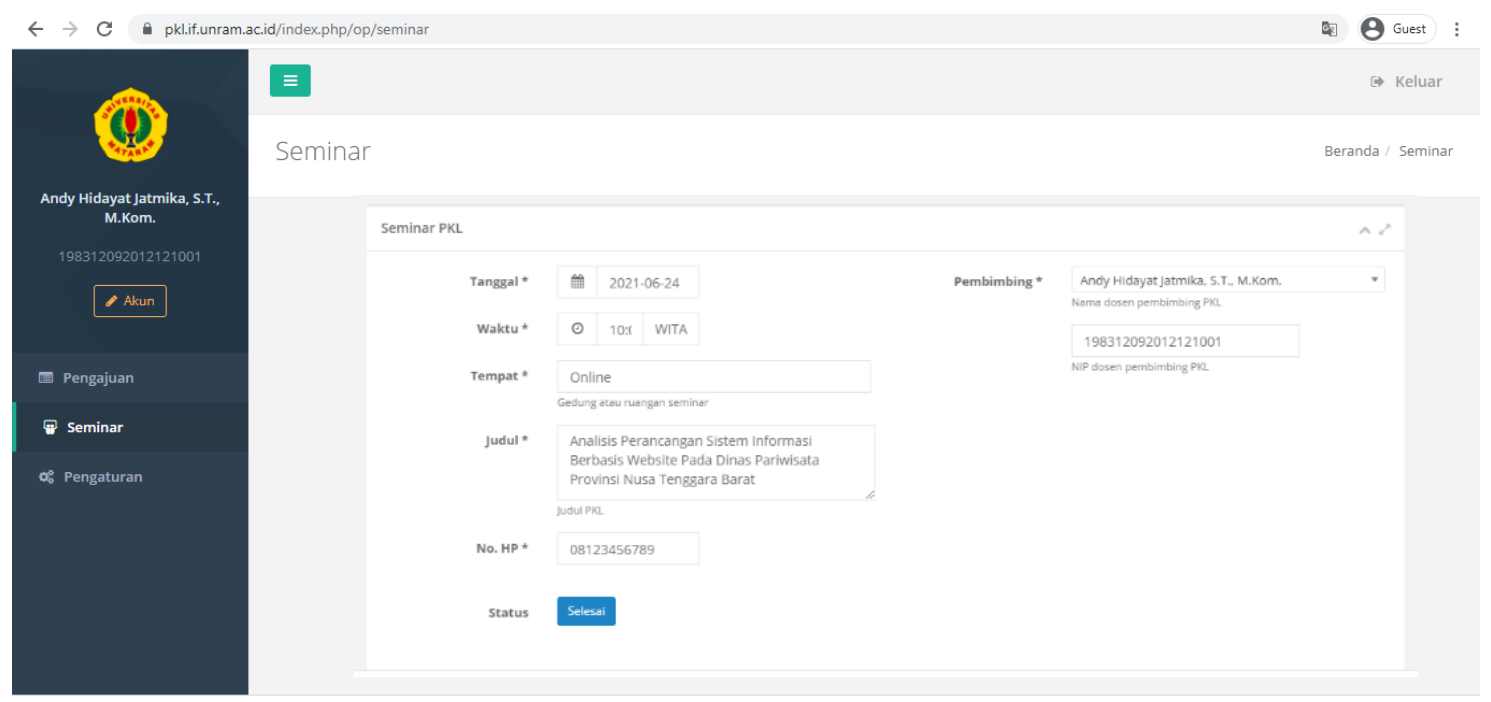

Gambar 6. Halaman permohonan seminar PKL

Pada Gambar 6 merupakan tampilan halaman permohonan seminar PKL. Apabila mahasiswa telah menyelesaikan proses PKL dan penyusunan laporan, maka mahasiswa dapat mendaftar seminar secara online melalui sistem informasi PKL. Pada halaman ini mahasiswa diharuskan mengisi jadwal pelaksanaan seminar PKL seperti tanggal, waktu, tempat, judul, nomor telepon dan nama dosen pembimbing. Selanjutnya sistem akan menyimpan jadwal seminar PKL mahasiswa tersebut. 


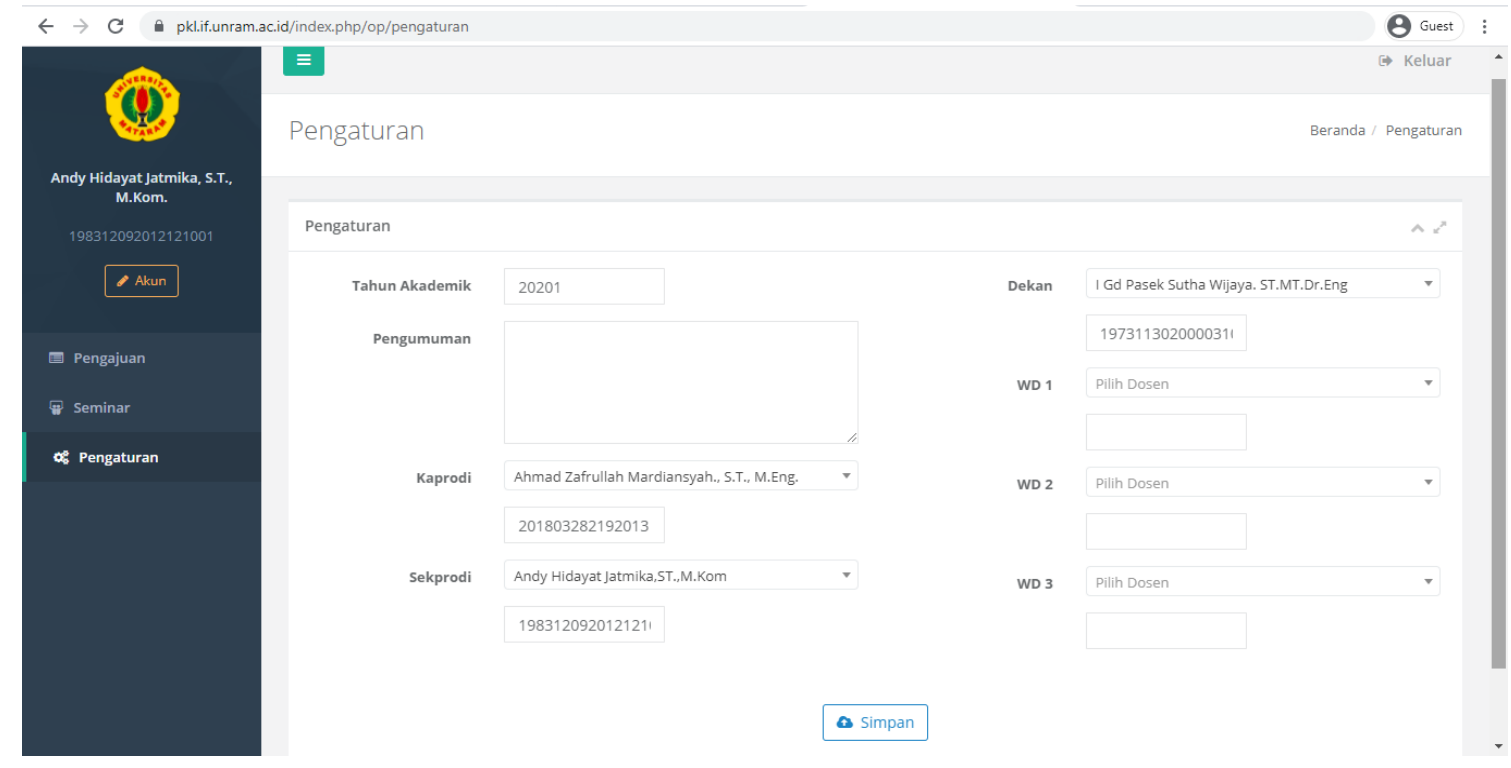

Gambar 7. Halaman pengaturan admin sistem

Gambar 7 merupakan halaman khusus untuk admnistrator sistem informasi PKL. Administrator merupakan orang yang ditugaskan untuk mengelola sistem, yaitu staf prodi Teknik Informatika. Pada halaman ini administrator dapat mengelola mahasiswa yang sedang melakukan proses PKL serta diharuskan menginput tahun akademik, nama kaprodi, sekprodi, dan dekan untuk proses administrasi sesuai dengan SOP PKL.

\subsection{Pengujian Sistem}

Pada bagian ini merupakan penyajian berupa gambar uji coba sistem yang dilakukan oleh 3 (tiga) orang staf prodi Teknik Informatika. Pengujian sistem oleh staf dilakukan agar dapat diketahui apakah terdapat hal-hal yang masih kurang sesuai dengan kebutuhan staf dari sistem yang telah dibangun seperti fitur-fitur, tampilan antar muka, dan kecepatan akses. Selain itu dilakukan pengujian sistem juga terhadap 7 (tujuh) orang mahasiswa prodi Teknik Informatika karena sebagian besar pengguna sistem PKL adalah mahasiswa. Pengujian Sistem Informasi PKL oleh staf dan mahasiswa dapat dilihat pada Gambar 6, Gambar, 7, Gambar 8, dan Gambar 9.

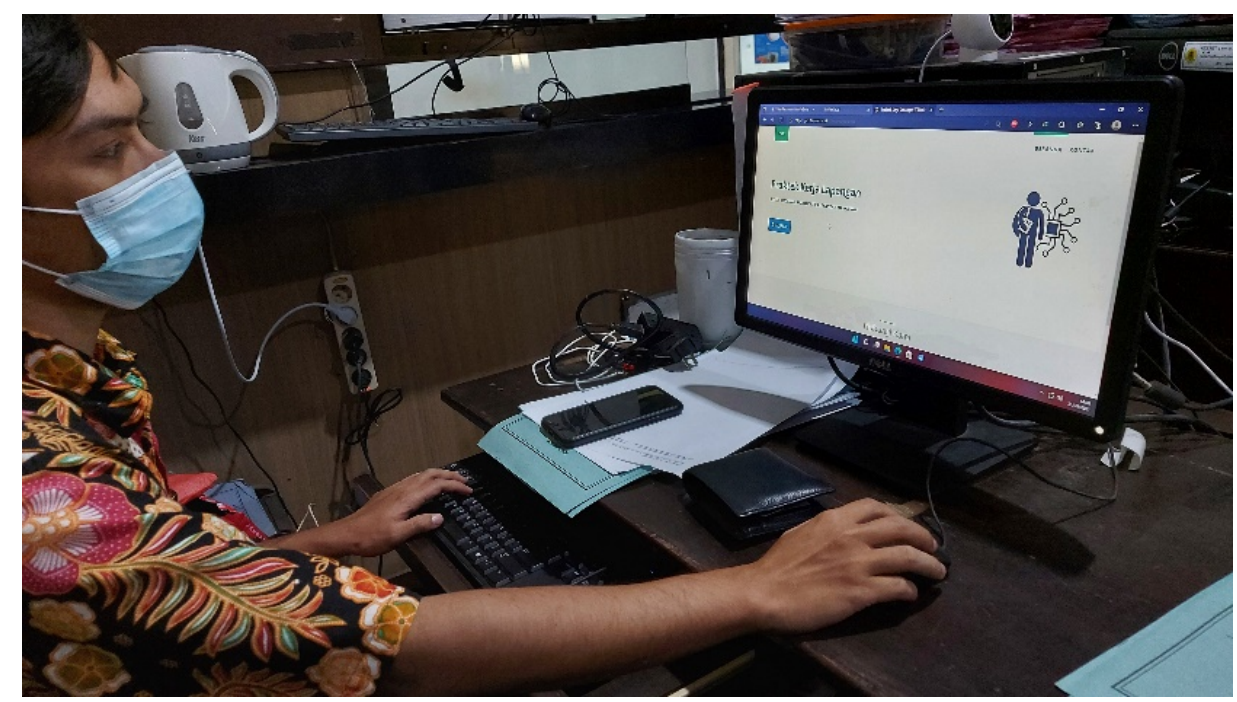

Gambar 6. Uji coba sistem oleh staf prodi 1 


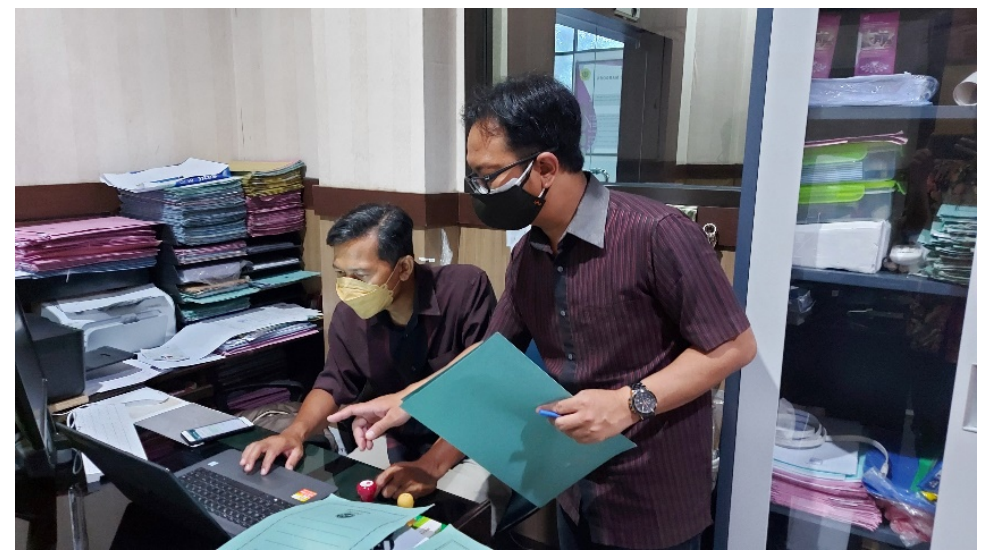

Gambar 7. Uji coba sistem oleh staf prodi 2

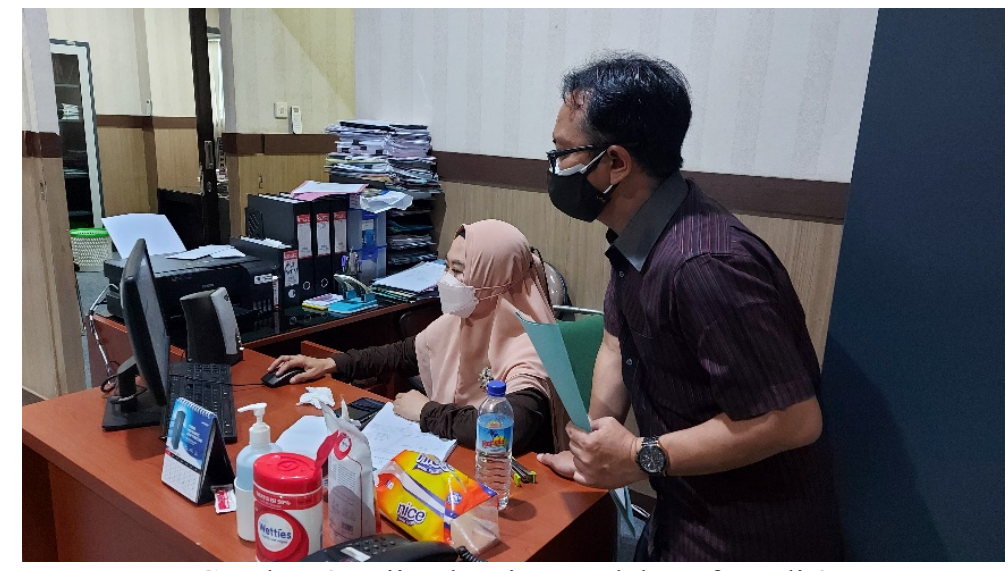

Gambar 8. Uji coba sistem oleh staf prodi 3

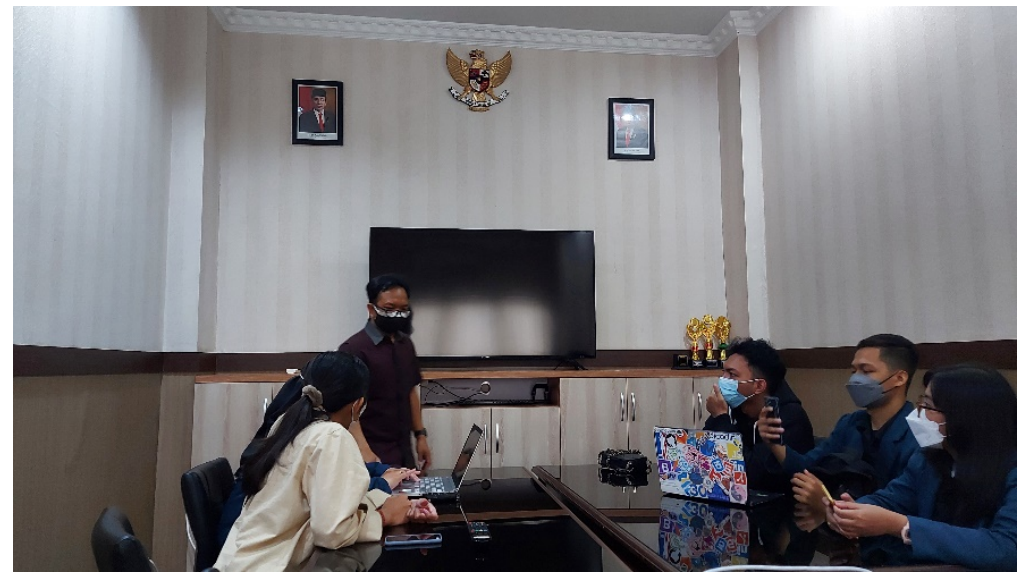

Gambar 9. Uji coba sistem oleh beberapa mahasiswa

Setelah melakukan pengujian sistem secara langsung, responden juga diharuskan mengisi kuesioner untuk mengetahui apakah sistem informasi PKL ini telah sesuai dengan yang diharapkan dan juga sebagai dokumen evaluasi sistem. Responden terdiri dari 3 (tiga) orang staf Prodi dan 7 (tujuh) orang mahasiswa Teknik Informatika angkatan 2018 yang pada semester Gasal 2021/2022 ini akan melaksanakan PKL.

Parameter pengujian yang digunakan pada metode ini adalah :

a. Apakah sistem informasi PKL yang dibuat sudah sesuai dengan kebutuhan staf dan mahasiswa?

b. Apakah sistem informasi PKL yang dibuat mempermudah aktivitas staf dan mahasiswa dalam proses administrasi PKL? 
c. Apakah sistem informasi PKL yang dibuat mudah digunakan?

d. Apakah sistem informasi PKL memberikan informasi yang detail?

e. Dalam tata letak (desain), apakah sistem informasi PKL mudah untuk dipahami?

Responden akan diberikan pilihan jawaban dari pertanyaan-pertanyaan di atas, yaitu :

a. Sangat Baik

b. Baik

c. Cukup

d. Kurang

e. Sangat Kurang

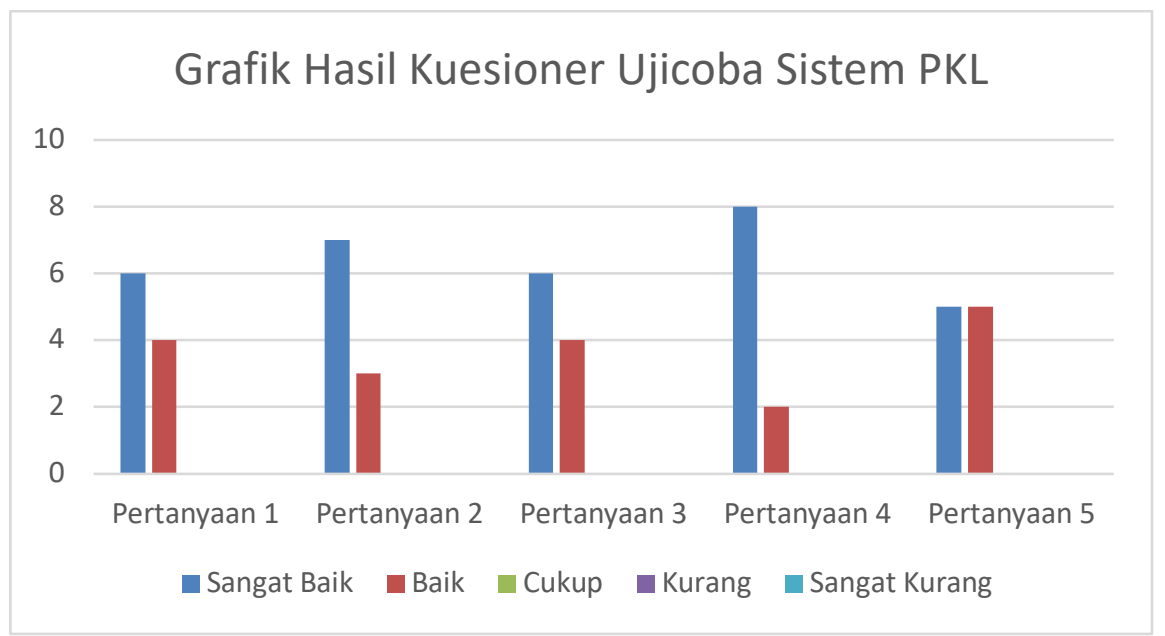

Gambar 10. Grafik hasil kuesioner ujicoba Sistem Informasi PKL

Gambar 10 merupakan grafik hasil kuesioner yang dilakukan terhadap 10 orang responden yang terdiri dari staf dan mahasiswa. Berdasarkan grafik dapat dilihat bahwa rata-rata responden menjawab dengan pilihan Sangat Baik dan Baik yang berarti bahwa Sistem Informasi PKL ini telah sesuai dengan apa yang diharapkan.

\section{KESIMPULAN DAN SARAN}

Dari hasil ujicoba sistem informasi PKL, dapat ditarik kesimpulan :

1. Berdasarkan hasil pengujian fungsionalitas sistem, fitur-fitur yang terdapat pada Sistem Informasi PKL telah berjalan dengan baik.

2. Dari sisi pengguna, sebanyak $64 \%$ menyatakan bahwa Sistem Informasi PKL yang telah dibangun sudah Sangat Baik, dan sebanyak 36\% menyatakan Baik. Ini berarti Sistem Informasi PKL telah sesuai dengan apa yang diharapkan oleh pengguna.

Adapun saran untuk pengembangan selanjutnya adalah perlu adanya fitur distribusi dosen pembimbing PKL, fitur notifikasi bahwa mahasiswa telah selesai PKL, notifikasi bahwa terdapat mahasiswa yang sedang mengajukan PKL, dan fitur surat menyurat PKL yang terintegrasi dengan sistem e-sign Universitas Mataram.

\section{DAFTAR PUSTAKa}

[1] Bisnis.com., "Belajar Tatap Muka: Mataram Perpanjang Program Belajar dari Rumah", 2019, [Online]. Available : https://kabar24.bisnis.com/read/20210103/79/1338009/belajar-tatap-muka-mataram-perpanjangprogram-belajar-dari-rumah.

[2] D.N. Avianty, A.H. Jatmika, dan L.M. Ulum, "Sistem Informasi Manajemen Aset pada BPKAD Provinsi Nusa Tenggara Barat Berbasis Website dengan Framework Laravel", Jurnal Begawe Teknologi Informasi, vol. 1, No. 1, September, 2020.

[3] Pangestika, "Sistem Informasi Manajemen dan Manfaatnya bagi Perusahaan", 2020, [Online]. Available: https://www.jurnal.id/id/blog/mengenal-sistem-informasi-manajemen-dan-manfaatnya-bagi-perusahaan/ 
[4] Ayuningtyas, "Pemanfaatan Teknologi Web Service Untuk Integrasi Sistem Layanan Materi Pelajaran Terdistribusi". Jurnal Angkasa, 2019.

[5] A. Zubaidi and R. Ramdani, "Layanan Dan Informasi Akademik Berbasis Bot Telegram Di Program Studi Teknik Informatika Universitas Mataram," J. Teknol. Informasi, Komputer, dan Apl. (JTIKA ), vol. 1, no. 1, pp. 103-110, 2019, doi: 10.29303/jtika.vli1.27.

[6] W3C, "Web Service Architecture," W3C Working Group Note, 2004. https://www.w3.org/TR/ws-arch/ (accessed Feb. 14, 2019).

[7] A. Hanif, "Basis Data Basis Data," Arif Basofi, S.Kom. MT. Tek. Inform. PENS Makal., pp. 1-19, 2016.

[8] Anhar, "Panduan Menguasai PHP dan MySQL Secara Otodidak", Jakarta: Mediakita, 2010. 